\title{
Psychological problems of late adoption as observed in Brazil through a cultural-historical approach
}

\author{
Carla Anauate \\ Universidade Nove de Julho/IPAF Lev Vygotsky, São Paulo, Brazil
}

\begin{abstract}
This work discusses certain cultural-historical concepts relating to late adoption. This term is used for the adoption of children over 2 years old. Unfortunately most people do not wish to adopt children over 2 years old. Generally they seek newborn babies, which are a rare population, probably because of birth control campaigns. The children who are available in orphanages are older children who are unwanted. This paper tries to deal with this issue emphasizing that relationships are built within a family, transforming those involved. It lays out principles for a successful adoption and illustrates this matter with a case study. Relationships should be provided so that people can interact. This interaction will lead to the transformation of all of those involved within the established relationship, which constitute the human being. We intend to demystify the difficult matter of late adoption, which is one of the key aspects concerning the return of the child to an orphanage. The adaptation of late adopted children is said to be more difficult, but when we believe that human beings can change and be modified through the relationships they establish, we see a promising possibility for late adoption. Late adoption can be successful when we view it from a relational point of view, stressing that relationships transform all the individuals involved within the group.
\end{abstract}

Keywords: adoption, relationship, mediation, transformation, children, cultural-historical

\section{Introduction}

Adoption is defined in ECA (Estatuto da Criança e do Adolescente,1994) as a modality of putting a person into a substitute family. It happens through a judicial process in which the specific competence is of the Judge of Childhood and Adolescence. It only occurs when all possibilities to return the child to the original family have been considered.

Therefore it is necessary for the biological parents to authorize officially. This is called destitution of parenthood. ECA (1994) says that adoption gives the condition of parenthood to the people who adopt. It promotes the insertion of the child into the family environment in a definitive way. It is irrevocable. The adoptive par- 
ents have to be at least 16 years older than the adoptee. The adopted child will have the same rights that a biological child has.

Adoption is a theme that has been very thoroughly considered within culturalhistorical psychology, because it includes the issue of the relationship being fundamental for the constitution of the human being (Bock, 2002). We believe that the individual only constitutes himself when in contact with another. When we talk about this theme, we notice that relationships transform human beings, so when an adoption happens, not only the adoptive parents but also the adopted child are subjects of transformation.

In this way we believe that a late adoption is best analysed when seen from a cultural-historical point of view. In contrast to other proposals, the cultural- historical theory considers the human being as a subjective individual who develops himself in an intrapersonal way when in contact with an interpersonal world of relationships. (Vigotskii, 2001).

It is within the relationship with the other that the human being develops himself and internalizes the world around. In this case the chances of a late adoption succeeding increase very much, because behavior and personality are capable of being modified all the time within the relationship between an individual and the world. People have an active and social interaction with society.

When we talk about a successful relationship, we consider the possibilities of a bad result in a relationship and a possible return of the child to the shelter home where he was living before. This is common particularity with older children who are in the late adoption preparation period. But what is success or failure when we talk about a relationship? Do we turn back a biological child? If so, to whom?

This work proposes a reflection on the adoption universe. When we reflect on this subject we believe that a new door will open up to think more profoundly about the issue of late adoption. We intend to look at this universe through the cultural-historical theory, emphasizing that relationships can transform people. Late adoption is a difficult and controversial theme to approach when we consider adoptions in general.

Late adoption is considered when the child is older than two years and can perceive himself as different from the other and from the world. The child should have a certain level of independency to deal with his basic needs. It is important that the child desires to be adopted. A slow approximation and a good preparation period should be provided between the child and the adoptive family for better disclosure of the adoption.

In late adoptions it is known that the more time the child stays at the shelter home, the more risky it becomes for adaptation within an adoptive family. The child frequently tests the love of the adoptive parents. Children who were turned back after a period of living together can have greater difficulty in trusting and accepting a new family. The self-esteem of the child may be fragile because he may be feeling guilty at having been abandoned, rejected, and turned back to the shelter home. Therefore careful psychological work should be done with these children for a better adaptation to the new realities. This psychological work includes individual sessions as well as technical orientation at the Forum. 


\section{Adoption in Brazil}

Since 2008 Brazil has had the Cadastro Nacional da Adoção, which formalized candidates for adoption and ordered them based on regions. In 2009, 4,253 adoptions took place in São Paulo.

In Brazil most of the children are adopted before they reach 3 years old. After this age things become more complicated. Most of the older children are either adopted by foreigners or remain at shelter homes. Research (Weber, 1995) has revealed that most adoptive parents believe they will have problems with late adoption because of prejudicial factors such as:

- Difficulty with the child's education;

- An institutionalized child may have bad habits;

- It is better to conceal from the child that he is adopted, and this is impossible with late adoption.

Late adoptive parents normally have a specific profile (Francis, 1997):

- The individuals are more stable emotionally

- Have good self esteem and a positive vision of themselves

- High maturity level

The theme of late adoption is being raised increasingly often. Most of the candidates for adoptive parents want a child up to 2 years old. We have the following data:

- From 2008 onwards in Brazil:

- $\quad 36 \%$ only accept a white child

- $\quad 32 \%$ are indifferent to color

- $\quad 27 \%$ want a child younger than 1 year old

- $\quad 50 \%$ accept a child with physical problems

- $\quad 32 \%$ accept siblings

Camargo (2005) provides us with data that in recent studies children have been abandoned by their biological families and ended up being raised in institutions. Few children are adopted by families, the majority are excluded socially and end up living on the streets. The author identifies that in Brazil the model of adoption used is still the classical one in which the reasons to adopt are related to the wellbeing of the couple, and not of the child.

This reality has been changing. Updates in Brazil show that there is a new adoption culture in which there is a search of families for children and not of children for families. This new vision contemplates modern adoptions which include late adoptions, adoptions of groups of siblings, adoptions of children with special needs and/or with HIV, etc. The best interests of the child is the focus, and this interest should be provided by a family and not an institution (Costa \& Rossetti-Ferreira, 2007).

Puretz \& Luiz (2007) assert that there is still a long way to go to minimize concerns related to late adoption. The authors mention that all involved in this matter need to be alert to possibilities of promoting the adoption of institutionalized children. Arnold (2011) points out that it is very important to use a multi-professional 
working team to inform and educate people through means of lectures, which will answer doubts and discuss matters relating to prejudice. Campaigns would also be very helpful to inform the population and contribute to tackling prejudices and myths on this matter, contributing to their prevention and solutions for abandoned children. All professionals in the area should be present in order to promote new visions and paths for late adoption.

\section{Preparation period}

Increasingly, we consider it highly important for preparations to include everyone involved in the adoption process. Preparations include: interviews, psychotherapy (principally for the child if he has already been turned back), visits to the Forum, in the shelter home, and in the adoptive home. There are support groups for adoption in Brazil which are recommended to adoptive parents so that they can exchange experiences and doubts.

A period of adaptation is fundamental - a being-together period helps to build up parenthood bonds. These bonds require effort, dedication, hard work and time. Both parties - adoptive parents and the adoptive child - should invest in the relationship with love, to overcome difficulties and differences. Vygotsky (1994) points out that it is essential to relate to each other because it is only within relationships that one can constitute his inner self and modify himself and the other. Therefore the cultural-historical theory underlies this work and aims for successful adoption when it emphasizes that people are in constant change when in relationships with other people and the world around them.

Adoption is irrevocable, so this preparation period is fundamental for everyone to get to know each other. A crisis always happens when a new member arrives in a family, and there is an accommodation period to go through. In a crisis there are always risks, but also opportunities for growth.

Campos (2010) pointed to some specific characteristics typical of the period of preparation:

1) Regressive behaviors appear in the child - it is as if the child becomes a newborn baby and is ready to be born again.

2) Aggressiveness - the child passes through emotional outbursts. The adoptive parents should contain this anger and provide psychotherapy for the child.

3) Aggressiveness primordially towards the adoptive mother - the fear of being abandoned again brings out hostile attitudes. It is a form of protection from frustration.

4) Quick rhythm of global child development.

5) Dealing with social prejudice - comments raise anxieties and fear towards the adoptive parents.

6) Significant effort of the child to identify himself with new parental models.

7) Build-up of parenthood bonds having to pass quickly through many stages - all the processes occur simultaneously. 
8) The parenthood bond can be done in a different way - everyone loves and shows affection in a different way.

9) Acquisition of new habits - takes time to modify habits.

10) Acquisition of new food habits - children learn a lot through imitation, so stimulate his sense of taste.

11) The child builds up a new identity.

12) Feelings of vulnerability, impotence and guilt - it is common to have ambivalent feelings.

13) Mobilization of intense and contradictory emotions - bonds are created depending upon how much they are nurtured.

14) The child presents himself as mature in some aspects and immature in other aspects.

Campos (2010) affirms that it is difficult to be completely ready. It is important to:

- Count on the support of family and friends,

- Go to adoption-specific support groups,

- Read about the subject,

- Specific and professional help can also be important.

\section{Preparation course of adoption}

In order to provide better preparation for parents that want to adopt a child, we organized a Preparation Course of Adoption focusing on these relational objectives. Participation in this course is required under Brazilian law. Only those who participated of this course are able to officially enter the Cadastro Nacional de Adoção. In this way we suggest a format of this course that focuses on the Cultural- Historical theory to potentialize human relations.

Preparation Adoption Course:

1rst DAY:

- The psychologist and Social Assistant receive the participants.

- Presentation of participants and the technical group promoting interchange aiming for development.

- Presentation of the actual law of adoption, and aspects of adoption in the country where this course will take place.

- Film: Delicate Choice - this is a film specifically about adoption, including speeches of adoptive parents and the technical group which works with this specific theme. This film aims to provide information. It is an instrument which mediates specific actualized data about legislation, and presents case studies that illustrate the facts.

- Comments about the film and about general adoption matters. This discussion will be followed by the psychologist and Social Assistant emphasizing the importance of listening to others, the meaning of adopting a child, and the state of being parents. It is important to give an opportunity to everyone present to express their sensations and perceptions on the content presented on the film. According to the cultural-historical theory, this promotes the development of the people involved, through a process of internalization. 
- A speech from a couple who adopted a child. This speech is of great importance to break down pre-established barriers of prejudice against adopting older children. The couple tells the group about experiences related to the relationship they have with their late adopted child. They focus on what their expectations were before adopting the child and what actually happened after they started to live together, and adopted officially. The aim of this speech is to show the group that, according to Bock (2002), people modify, and modify the other, when in relationship with the other.

- End with a recorded speech of a child who was turned back to the shelter home because of inadaptation. This recorded speech will serve to help to make the future adoptive parents aware of the emotional results that occur after an unsuccessful preparation period. It is important to focus on the fact that this child is a human being with subjectivity and emotions, who has already suffered on one or more occasions the abandoning of a parent. Subjectivity, within the culturalhistorical theory is built up in a process of interrelations, so providing good quality relationships among adoptive parents and children is the aim of this preparation course.

\section{2nd DAY}

- A reunion in the shelter home where the child lives. This reunion has the goal of ensuring that the future adoptive parents observe the reality of the children. Observation of the environment and how care givers look after the children. This proposal has the objective of promoting the opportunity to spend a day with children who live in shelters and to promote relationships. Vygotsky (1994) affirms that within relationships, the interpersonal becomes intrapersonal. Therefore this will be a moment of reflection - are these future adoptive parents prepared for the adoption?

- Activities of adults and children together. The activities are to ensure that future adoptive parents and children can interact for a period of time. This interaction is a crucial moment needed to relate and to transform concepts.

- A snack can be offered by the future adoptive parents to the children so they can have more time to talk and be together in an informal setting. This is also an opportunity, as pointed out by Aguiar (2002), to "objectivate subjectivity and subjectivate objectivity".

- At the end of this reunion the technical group would ask the couples to reflect at home about the two days of the course, and bring to the next meeting a item (a drawing, poem, text, etc.) to discuss with the whole group. This gives the future adoptive parents a chance for reflection. They will be able to reflect on their feelings and emotions through an artistic production and share this with other participants to promote a moment of sharing thoughts and reassessing realities. According to the cultural-historical theory, this item should reflect the process of internalization of all experience so far lived through.

\section{3rd DAY}

- The participants are received.

- Film: Different Adoptions. This film, along with the other film, presents notions on various possibilities for adoptions: late adoptions, inter-racial adop- 
tions, adopting a sick child, adoption of siblings, etc. This film will provide the opportunity for participants to get information and open their minds to other forms of adoption. The aim is always to stress that relationships transform everyone involved in the process.

- Each couple will present an item brought from home (a drawing, poem, text etc.) relating to impressions on the first and second day, and discuss it with the group. The process of exchanging experiences in an interpersonal matter promotes intrapersonal change.

- Closing session with general comments. The Psychologist and Social Assistant will conduct this closing sessions, allowing all the participants to say how they first arrived for the course, and how they are now. If the course has in any way changed their vision of adoption and the expectations of all participants, this is an opportunity to externalize emotions and changes that occurred in this interpersonal process.

- At the end, the Psychologist and the Social Assistant will make specific comments of their expertise, help the participants going through last-minute doubts, and give support. They will also ask the participants to give feedback on the course.

\section{Cultural-historical theory and late adoption}

Under the cultural-historical theory according to Bock (2002), man is constituted through the relationship that he establishes with his social world and the people around him. It is contact and exchange that permits the development of a human being. Therefore the child will be brought up through the relationship that he has with other people. People are a result of the relationships they experience. Subjectivity is socially constituted.

In this matter he will internalize the world and constitute his subjectivity by means of the relationships and the life he will live. González Rey (1995) considers that the constitution of individual subjectivity is a singular process that emerges from the person in contact with the actual environment. The social world becomes subjective when it is converted into something relevant for the development of the human being.

Parents are the mediators between the child and the world. The parents will provide interaction which permits the child to develop as a human being belonging to the universe. Vygotsky (1995) infers that through contact with the world of relationships, the child internalizes the instruments, actions and relationships that are presented to him by others, permitting the development of superior psychological functions. In this way the child will grow as a social and active human being.

Aguiar (2002) points out that man is in a constant relationship with the world, intervening in it and at the same time being affected by it, and internalizing and registering it. Therefore the psychological world is constituted from the relationships of man with the objective, social and cultural world. Man constitutes his psychological world within the relationship he has with the world, objectivating subjectivity and subjectivating objectivity. 
Vygotsky (1994) affirms that such instruments, actions and social relationships are presented to the child, in the first place, on the interpsychological and social level, and only afterwards in an intrapsychological, internal and subjective level, through the process of internalization.

The initial relationship of men with their external environment is mediated: the child needs to manipulate objects, live situations, and establish relationships with other persons in the social environment to be able to appropriate, internalize, and mentally represent objects, events and relationships. This process of relational experience of the child is the driver for the development of superior psychological functions (Vygotsky, 1995).

\section{Case study}

I will illustrate this work with a case study of two children: a brother and a sister: the boy is four years old and the girl is six. They were put in different adoptive homes three times, each time unsuccessfully.

Various trials were made for the children to return to their biological family, but the only possible member, a grandmother, said she lacked the conditions to take care of them. The conclusion was to let us put the children up for adoption. The shelter home started preparations.

The professionals from the shelter home started to prepare the children to meet a new family. A family from the Cadastro Nacional de Adoção was contacted and came to meet the children in the shelter home. The family and children both showed tenderness towards each other. On the same day the children went to live with the couple during the preparation period. 20 days later the couple brought back the children to the shelter home, saying that they did not adapt. The girl said that she did not like staying with the family. The boy could not express himself.

The children were warmly received back in the shelter home, and participated in art therapy activities. The girl started to present a rebellious attitude, and did not accept rules and limits. She returned to pre-school and was very well received by everyone. Both the shelter home and the school worked together to provide reflection on rules and obligations with the child.

Six months later another couple from the Cadastro Nacional da Adoção started to visit the children. This time a timetable was drawn up for the visits, and twice a week the couple stayed in the shelter home with the children for a period of time. Afterwards the couple took the children several times to a park close to the shelter home to start to build up affectionate bonds. During this time the children received orientation from the professionals working at the shelter home on how to live in a family, and about rules, limits, tenderness, affection, and relationships between siblings.

After one month the children went to spend a weekend with the couple in their house. The future mother said that the girl did not behave well and decided to give up her approach for these children. The children were attended by a psychologist. They were well received back in the shelter home, where they started to do a Life Story Notebook with pictures of the most important moments of their lives. 
Two months later a new couple started to approach them. Visits started to happen in the shelter home and then at their house. A new house, a new couple, a new preparation for an adoption period. But a new disappointment.

Three months later the couple gave up, saying that the children were not adapting and that the couple had relational problems. The children were back to the shelter home again with a very tender reception. The children continued their psychotherapy, art therapy, and leisure and cultural activities. Now we are introducing the children to a new couple. This couple has three grown-up children of their own and one adopted girl, the same age as the girl in this study case. One of their daughters has already worked in the shelter home and has bonds with the children. We are preparing the children and the couple, talking about everything that these children have already gone through. The couple have already met the children inside the Forum. They played for two hours in the play room inside the Forum. Apparently everything is going well.

The couple is being oriented on how much people change when in a relationship with another person, how subjectivity is built up within relationships, and how people change all the time. We drew up a timetable of meetings for the couple and children to be together. A flicker of love is emerging between the children and adoptive parents. The girl, who used to be more difficult to approximate, is getting close, and trying to overcome the feeling of a abandonment so familiar from past relationships. The boy, as usual, is already calling the adoptive parents: "Mom" and "Dad". Bonds are being built in a context of hope. This time we hope to achieve success - a successful late adoption case. According to the cultural-historical theory, relationships promote change, and people modify each other when in relationships with each other. Opening up to a relationship is not easy, we can say it is a challenge. It is important to remind ourselves that these children tried to open up and to relate, several times. We can consider these children to be resilient, because after three unsuccessful experiences, they are trying again. As Bock (2002) points out, every new relationship is an opportunity for growth and internalization of new possibilities of change. Therefore, after three couples, we are working on love, care and tender feelings. It all depends on the relationships established within an open heart, and the most naive feeling of all - pure love!

\section{Conclusion}

Adoptive parents serve as mediators of the world to their child. In this way the parents are responsible for presenting the world and all concerned within it to this child. This responsibility involves the way the child will internalize the world. It does not matter how old the adopted child is because his subjectivity will be built within the relationships he has, and his experiences in life.

In this way, Bock (2002) affirms that man transforms and is transformed in a constant process. Therefore, relationships constitute man, so adoptive parents will raise their child and educate him in the way they believe is best, within social principles.

It is important to point out that relationships involve a two-way exchange, therefore one constitutes the other and transforms the other, in a process which focuses on the best adaptation to reality. 
- "Of all, three things last:

- The certainty of being always restarting...

- The certainty that we need to continue...

- The certainty that we will be interrupted before it ends....

- Therefore we should transform the interruption into a new path....

- The fall, into a dance step...

- The fear, into a stairway...

- The dream, into a bridge...

- And the search, into a meeting point..."

\section{References}

Aguiar, W. M. J. (2002). Consciência e atividade: Categorias fundamentais da Psicologia SócioHistórica. In Bock, A.M.B. Psicologia Sócio-Histórica (uma perspectiva crítica em psicologia). São Paulo: Cortez.

Arnold C. P. (2011). Adoção tardia: do estigma à solidariedade. Amicus Curiae, 5(5).

Bock, A. M. B.(2002). Psicologia Sócio-Histórica (uma perspectiva crítica em psicologia). São Paulo: Cortez.

Camargo, M. L. (2005). A adoção tardia no Brasil: desafios e perspectivas para o cuidado com crianças e adolescentes. São Paulo.

Campos, M. V. (2010). Características da Fase de Estágio de Convivência na Adoção Tardia. In: Galvão, I., Roque, E. (Coord.). Aplicação da Lei em uma Perspecitiva Interprofissional: Direito, Psicologia, Psiquiatria, Serviço Social e Ciências Sociais na Prática Jurisdicional. Rio de Janeiro, Editora Lumen Juris.

Costa, N. R. A. \& Rossetti-Ferreira, M. C. Tornarse Pai e Mãe em um Processo de Adoção Tardia. Psicologia: Reflexão e Crítica, 20(3), 425-434.

Estatuto da Criança e do Adolescente. (1994). Ministério da Educação, Assessoria de Comunicação Social, Brasília: MEC, ACS.

Francis, L. J. (1997). The relationship between Rosenberg's construct of self Esteem and Eysenck's two-dimensional model of personality. Personality and Individual Differences, 22(1), 139.

González, R. F. (1995). Personalidad y desarrollo. Havana, Pueblo y Educación.

Puretz, A. \& Luiz, D. E. C. (2007). Adoção tardia: desafios e perspectivas na sociedade contemporânea. Disponível em: http://dialnet.unirioja.es/servlet/articulo/codigo-4024346

Vigotskii L. S., Luria A. R., Leontiev A. N. (2001). Linguagem, desenvolvimento e aprendizagem. São Paulo, Ícone Ed.

A Formação Social da Mente. (1994). São Paulo: Martins Fontes.

Obras Escogidas. (1995). España: Visor.

Weber, L. N. D. \& Gagno, A. P. (1995). Onde estão os vínculos afetivos das crianças institucionalizadas? Em Congresso Latino-Americano de Psiquiatria da Infância e da Adolescência (Org.) Cadernos de Resumos X Congresso de Psiquiatria (p. 25). Curitiba. 